\title{
Preliminary toxicology profile of Dennettia tripetala (Pepper Fruit) methanolic leaves extract
}

\author{
Joseph Chukwufumnanya Mordi ${ }^{1 *}$, Patrick Chukwuyenum Ichipi-Ifukor ${ }^{2^{*}}$ (D), Godfery Rume Kweki ${ }^{1,2}$,
} Rita Ngozi Ichipi-Ifukor ${ }^{3}$, John Chukwuma Oyem ${ }^{4}$ and Uche Dennis-Eboh ${ }^{2}$

\begin{abstract}
Background: Dennentia tripetalla (Pepper Fruit) belongs to the Annonaceae family and is abundant in Nigeria. Its fruit in folklore medicine is used for treatment of varying ailments. While ample research evidence exists on the plants fruit and seed, no current study exists on the toxicological profile of the plant leaves.
\end{abstract}

Methods: qualitative and quantitative phytochemicals and In vitro antioxidant assays were carried out using standard methods. The acute toxicity study indicates that the $\mathrm{LD}_{50}$ was higher than $2000 \mathrm{mg} / \mathrm{Kg}$ body weight. Subchronic toxicity studies was carried out using five groups of rats. Group 1 served as control, 2-5 received $100 \mathrm{mg} /$ $\mathrm{Kg}, 200 \mathrm{mg} / \mathrm{Kg}, 500 \mathrm{mg} / \mathrm{Kg}$ and $1000 \mathrm{mg} / \mathrm{Kg}$ body weight orally for 28 days.

Results: Post-administration biochemical analysis indicates there was increased weight in rats administered 100 $\mathrm{mg} / \mathrm{kg}$ and $200 \mathrm{mg} / \mathrm{kg}$ while it reduced in the $500 \mathrm{mg} / \mathrm{kg}$ group. Significant elevations of liver function markers were reported for $200 \mathrm{mg} / \mathrm{kg}$ and $500 \mathrm{mg} / \mathrm{kg}$ respectively. Serum and hepatic protein profiles remained unaltered. Renal function analysis revealed elevated serum urea and creatinine for 200 and $500 \mathrm{mg} / \mathrm{kg}$ groups, elevated serum $\mathrm{Na}^{+}$and $\mathrm{Ca}^{+}$and reduced serum $\mathrm{Cl}^{-}$for the $500 \mathrm{mg} / \mathrm{Kg}$ group. Elevated Kidney $\mathrm{K}^{+}$and $\mathrm{Ca}^{+}$levels, reduced $\mathrm{Cl}^{-}$ were significantly observed in $500 \mathrm{mg} / \mathrm{Kg}$ group. Significant rise in hepatic and renal lipid peroxidation was observed in 200 and $500 \mathrm{mg} / \mathrm{Kg}$ groups. There were observed disarmament of the antioxidant defense systems occasioned by rise and drop in tissue (hepatic, renal, testes, heart) Superoxide dismutase (SOD), Catalase (Cat), Glutathione-s-transferase (GST), Glutathione peroxidase (GPx) activities in the test groups relative to control. Histopathological examination indicated architectural aberrations at 500 and $1000 \mathrm{mg} / \mathrm{kg}$.

Conclusions: It concluded that the plant had significant phytochemical and antioxidant properties of medical interest and possessed toxic properties in rats when administered at a dose above $200 \mathrm{mg} / \mathrm{Kg}$ over a prolonged period of time.

Keywords: Toxicology, Dennettia tripetala, Acute toxicity, Chronic toxicity, Antioxidants, Oxidative stress

\footnotetext{
*Correspondence: mordijc@delsu.edu.ng; pcichipi-ifukor@delsu.edu.ng 'Department of Biochemistry, Faculty of Science Delta State University, Abraka, Nigeria

2Department of Medical Biochemistry, Faculty of Basic Medical Sciences

Delta State University, Abraka, Nigeria

Full list of author information is available at the end of the article
}

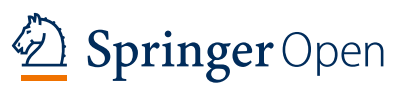

(c) The Author(s). 2021 Open Access This article is licensed under a Creative Commons Attribution 4.0 International License, which permits use, sharing, adaptation, distribution and reproduction in any medium or format, as long as you give appropriate credit to the original author(s) and the source, provide a link to the Creative Commons licence, and indicate if changes were made. The images or other third party material in this article are included in the article's Creative Commons licence, unless indicated otherwise in a credit line to the material. If material is not included in the article's Creative Commons licence and your intended use is not permitted by statutory regulation or exceeds the permitted use, you will need to obtain permission directly from the copyright holder. To view a copy of this licence, visit http://creativecommons.org/licenses/by/4.0/. 


\section{Introduction}

Plants have been identified as a major contributor to the sustenance of good health hence their uses have been widely reported $[1,2]$. Several pharmaceutical products used in modern medicine for treatment of several ailments are derivatives of plant-based products that have undergone various stages of isolation and purification [3, 4]. In addition, the World Health Organization reported that several populations in developing countries depend on herbal medicine in meeting their health needs [5]. With the increased search for natural products as an alternative to synthetic drugs, several screening processes has been carried out in different plant materials. This had provided useful observations that could lead to further investigation of the chemical and pharmacological potentials of these medicinal plants.

Dennettia tripetala (Pepper Fruit) is a plant that belongs to the Annonaceae family. It is abundant in the tropical rain forest region of Nigeria [6, 7]. It bears edible fruits which are green when unripe and pink when ripe with a pungent spicy taste. Evidence based on folklore medicine showed that the seeds are used for treatment of cough, fever, diarrhea and rheumatism [8,9]. The leaves were also reported to be used by locals as tea. Research evidence shows that studies conducted on the fruit (seed ripe and unripe) have reported it to possess some anti-diabetic, anti-analgesic, anti-inflammatory and neuro-pharmacological effects [9-11]. The seed have also been reported to possess anti-microbial properties due to its high levels of flavonoids, polyphenols and other medically significant phytochemicals [12-15].

Although the plant fruits and seeds have been extensively researched, only scant literatures have been specifically devoted to preliminary phytochemical and antimicrobial screening of Dennettia tripetala leaves [8, 16, 17]. At the time of this research, there is no evidence based studies on the in vitro antioxidant properties or toxicity profile of the leaves of this plant on any animal model, and based on the potential therapeutic benefits of the leaves of Dennettia tripetala, this study was carried out to access the phytochemical, in vitro antioxidant properties and the preliminary toxicological assessment of the methanol extract of the plant leaves.

\section{Materials and method}

\section{Collection of plant material}

Fresh leaves of Dennetia tripetala were harvested from a local farm in Umeghe-Abraka, Delta State, Nigeria. Samples of the leaf were taken to the Department of Botany Faculty of Life Science University of Benin, Benin City and was identified by a taxonomist Dr. Akinnibosun Henry Adewale as Dennettia tripetala (Family: Annonaceae). A voucher number UBH-D360 was deposited at the departmental herbarium.

\section{Plant extraction}

The authenticated plant samples were transported to the laboratory at the Department of Medical Biochemistry and air dried for a period of 2 weeks after which pulverization into fine powder was carried out using a Warring blender (Quilink QBL-20 L40 model). Extraction of the methanol extract was carried out as described by the method of Achuba [18] by soaking $500 \mathrm{~g}$ of powdered leaves in $70 \%$ methanol and allowed to ferment for $72 \mathrm{~h}$. At the end of the fermentation period, filtration was achieved using cotton wool and Wattman filter paper which was eventually concentrated using a rotary evaporator and later evaporated to dryness to obtain a finely separated crude extract powder in a water bath. The aqueous extraction employed the hot water extraction method previously described by George et al., [19] by boiling $500 \mathrm{~g}$ of the powdered leaf at a temperature of $100{ }^{\circ} \mathrm{C}$ for $10 \mathrm{~min}$ then allowed to cool. This was eventually filtered and the fine dry powder of the extract was obtained by same procedure described for the methanol extract. The yield obtained was $78.75 \mathrm{~g}$ for the methanol extract and $56.23 \mathrm{~g}$ for the aqueous extract. This amounted to a total yield of $15.75 \%$ and $11.25 \%$ respectively of the ground powder.

\section{Phytochemical screening \\ Qualitative phytochemical screening}

Determination of the presence of flavonoids, saponins, reducing sugar, and steroids employed the methods of Sofowora [20]. The method described by Trease and Evans [21] were used for determination of akaloids, cardiac glycosides and tannins.

\section{Quantitative phytochemical screening}

The quantitative determination of the phytochemicals used the methods that were reported by Harborne [22] for alkaloid, cardiac glycosides, reducing sugar and saponin contents. Method of Sofowora [20] was used for tannin contents estimation with tannic acid serving as standard.

\section{In vitro antioxidant assay}

The in vitro antioxidant capacities of the crude plant powder, aqueous extract and methanol extract were examined with four parameters using standard methods. The parameters and methods used were as follows; DPPH radical scavenging activity [23]; Nitric oxide radical scavenging activity [24], Ferric reducing antioxidant power [25] as reported by Iserhierhien and Okolie [26]. The lipid peroxidation (TBARS) inhibition assay was carried out using the method previously reported [27]. The methanol plant extract with the most in-vitro antioxidant capacity was evaluated for acute and subchronic toxicity. 


\section{Ethical considerations}

Study protocol was in consonance with the guidelines and declarations of Animal Research Ethics [28] and the World Medical Association [29] on animal use in biomedical research and it conformed to the animal rights law of the Delta State University (REC/FBMS/DELSU/ 19/078).

\section{Preparation of extracts for animal administration}

A stock solution of the plant extract was prepared by dissolving $2 \mathrm{~g}$ of the crude methanolic plant extract in $20 \mathrm{ml}$ of water to yield $100 \mathrm{mg} / \mathrm{ml}$. Individual dose was administered based on the dose per kilogram body weight of the animals.

\section{Acute toxicity test and lethal dose determination}

At the end of the in vitro antioxidant evaluation, the methanol leaf extract was reported to have a potent antioxidant potential compared to the aqueous extract. Based on this observation, the 16 rats shared into four groups of four animals each were subjected to acute toxicity test at a single dose of $500 \mathrm{mg} / \mathrm{Kg}$ body weight, $1000 \mathrm{mg} / \mathrm{Kg}$ body weight, $1500 \mathrm{mg} / \mathrm{Kg}$ body weight and $2000 \mathrm{mg} / \mathrm{Kg}$ body weight and monitored for $48 \mathrm{~h}$. During this period, the rats were observed to show mild signs of moodiness and inactiveness at doses of $1500 \mathrm{mg} / \mathrm{Kg}$ and $2000 \mathrm{mg} / \mathrm{Kg}$ body weights, respectively. There were no deaths observed within the $48 \mathrm{~h}$ period which is indicative of the fact that the $\mathrm{LD}_{50}$ was higher than the dose of $2000 \mathrm{mg} / \mathrm{Kg}$ body weight. Analysis of haematological parameters indicated a significant drop in PCV, HB and $\mathrm{RBC}$ values and rise in $\mathrm{WBC}$ values for rats administered the $1500 \mathrm{mg} / \mathrm{Kg}$ and $2000 \mathrm{mg} / \mathrm{Kg}$ body weights respectively. A further examination of serum liver function markers (ALT and AST) indicated an elevation of these parameters while the liver histopathology results for those administered $1500 \mathrm{mg} / \mathrm{Kg}$ and $2000 \mathrm{mg} / \mathrm{Kg}$ body weight indicated there were mild ballooning of the liver tissues. It was concluded that at the dose of $1500 \mathrm{mg} / \mathrm{Kg}$ and $2000 \mathrm{mg} / \mathrm{Kg}$, the plant extract exhibited some level of toxicity. These results are attached as supplementary data in support of the current study.

\section{Chronic toxicity evaluation experimental design Animal characteristic and acclimatization}

Following the outcome of the acute toxicity study, thirty male albino rats with weights between 140 and $160 \mathrm{~g}$ of about 12 weeks old were purchased from the animal house of Emma Mariae Research Laboratories and Consultancy, Abraka Nigeria. The animals were transported using rectangular perforated plastic cage $(30 \times 32 \times 68 \mathrm{~cm})$ to the animal house of the College of Health Sciences, Delta State University, Abraka Nigeria. They were allowed to acclimatize to the new conditions and stored in well-dressed wooden cages $(30 \times 40 \times 80 \mathrm{~cm})$ with a top opening covered with wire mesh to allow for easy ventilation and aeration. This was free of sharp edges and projections capable of causing injuries or accidental entrapment of their appendages. The environmental conditions comprised of an ambient temperature between $28 \pm 1{ }^{\circ} \mathrm{C}$, relative humidity $92 \%, 12: 12$ light and dark cycles and acclimatization lasted for 5 days.

\section{Animal storage facility and distribution}

The end of the acclimatization period was followed by the determination of the initial weight of the animals and random distribution into five groups of six rats each. The acclimatization conditions were sustained through the experiment and sawdust provided for use as beddings were changed daily so as to remove food debris and fecal droplets as well as minimize accumulation of moisture for optimal animal health. Free access to commercial rat chow and water were also maintained through the experiment. The first group served as the control and comprised of animals that were not treated with any dose of the methanol extract of Dennettia tripetala while the second, third, fourth and fifth groups comprised rats administered $100 \mathrm{mg} / \mathrm{Kg}, 200 \mathrm{mg} / \mathrm{kg}, 500$ $\mathrm{mg} / \mathrm{kg}$ and $1000 \mathrm{mg} / \mathrm{Kg}$ body weights respectively (see Tables 1 and 2). Treatment of the animal was done once daily for a period of 4 weeks ( 28 days). In the course of the experimental period, visible signs of weakness were observed in rats administered $1000 \mathrm{mg} / \mathrm{Kg}$ body weight this was followed by death of two rats in the group on the 12th day while further two died at the 18th day of the experiment. This observation was immediately followed by a sacrifice of the remaining two rats in the groups and their liver tissues harvested for histopathological analysis.

\section{Sample collection}

On the 29th day after an overnight fast, rats in the other groups were sacrificed following determination of their final weight. After cervical dislocation, the rats were dissected and blood samples collected via cardiac puncture

\begin{tabular}{|c|c|c|c|c|}
\hline \multirow[t]{2}{*}{ Group } & \multicolumn{3}{|c|}{$\begin{array}{l}\text { 1-28 Days } \\
\text { Drug Administration }\end{array}$} & \multirow{2}{*}{$\begin{array}{l}\text { Sacrifice } \\
\text { Day } 29\end{array}$} \\
\hline & & Death & & \\
\hline Control & - & - & & \\
\hline $100 \mathrm{mg} / \mathrm{Kg}$ & $+(1-28)$ & - & & \\
\hline 200 mg/Kg & $+(1-28)$ & - & & \\
\hline $500 \mathrm{mg} / \mathrm{Kg}$ & $+(1-28)$ & - & & \\
\hline \multirow[t]{2}{*}{1000 mg/Kg } & $+(1-18)$ & Day 12 & Day 18 & Day 18 \\
\hline & & +2 & +2 & \\
\hline
\end{tabular}

+ Signs indicates the presence of a factor while - sign indicates its absence 
Table 2 Qualitative analysis of secondary metabolites of Dennettia tripetala leaves extracts

\begin{tabular}{llll}
\hline Phytochemicals & Crude leaf Sample & Aqueous extract & Methanol extract \\
\hline Alkaloids & + & + & + \\
Saponins & + & + & + \\
Tannin & + & + & + \\
Cardiac glycoside & + & + & + \\
Reducing sugar & + & + & + \\
Flavonoids & + & + & + \\
Steroids & + & & +
\end{tabular}

$+=$ Present

while vital organs (Liver, Kidney, Heart and Testes) were harvested, weighed and transferred to labelled containers.

\section{Preparation of tissue homogenate}

The tissue homogenate of each organ was prepared in pre-chilled pestle and mortar using $0.5 \mathrm{~g}$ tissue per $4 \mathrm{ml}$ of cold normal saline solution. The homogenate was subjected to centrifugation at $5000 \mathrm{~g}$ for $10 \mathrm{~min}$ as previously reported [30] and the supernatant obtained was used for analysis. The serum was obtained by centrifugation of the clotted blood at $3000 \mathrm{~g}$ and the serum collected was stored at $-4{ }^{\circ} \mathrm{C}$ before biochemical analysis was carried out.

\section{Biochemical assays}

Following sample collection, serum and liver ALT, AST, ALP were assessed using a commercial diagnostic kit Teco diagnostics USA. Serum and kidney urea, creatinine and electrolytes were done using the commercial Randox diagnostic kit according to the manufacturers' instruction.

Assay for lipid peroxidation was done following method described [31], tissue antioxidants were done by the following standard methods highlighted; GSH [32], Catalase [33], Super oxide dismutase (SOD) [34] Glutathione-S-transferase (GST) [35] and Glutathione peroxidase GPx [36].

\section{Histopathological examination of liver}

Examination of hepatic architecture was carried out as previously described [30]. Harvested liver tissues were rinsed with chilled cold normal saline and was cut to a size of $(5 \mathrm{~mm})$ and then fixed with $10 \%$ formalin. Sectioning using a microtome was done following a $90 \mathrm{~min}$ dehydration period through $70 \%$, 90\% and 95\% absolute ethanol. Use of xylene for the clearing process was done for $2 \mathrm{~h}$ and followed by embedment with paraffin wax for another $2 \mathrm{~h}$ before sections of about $7 \mu$ thickness was cut, stained with hematoxylin and eosin (H\&E) and mounted using cover slips. Specimen examination followed by photographing was done under a light microscope.

\section{Method of data analysis}

Data analysis was carried out using analysis of variance (ANOVA) while group comparison was done using bonferroni at $P \leq 0.05$. Results were however presented in bar charts and tables as Mean \pm SD.

\section{Results \\ Qualitative phytochemicals screening of Dennettia tripetala leaves}

Results in Tables 1 and 2 presents the qualitative phytochemical screening of crude Dennettia tripetala, aqueous extract and methanol extract. All tested bioactive were present in all the samples of Dennettia tripetala leaves.

\section{Quantitative phytochemical screening of Dennettia tripetala}

Table 3 presents the result of the quantitative phytochemical screening of Dennettia tripetala leaves extract. Details of the result revealed that Flavonoids had the highest mean value of $6.09 \mathrm{mg} / \mathrm{g}, 4.76 \mathrm{mg} / \mathrm{g}$ and $5.89 \mathrm{mg} /$ $\mathrm{g}$ in all three samples of the leave extracts respectively. Steroids were the least for crude leaf sample $(0.36 \mathrm{mg} / \mathrm{g})$, and the methanol extract $(0.11 \mathrm{mg} / \mathrm{g})$ while saponins were the least in the aqueous extract $(0.09 \mathrm{mg} / \mathrm{g})$.

\section{In vitro antioxidant activity of Dennettia tripetala leave extracts}

Figure 1 presents the results of the in vitro antioxidant activity of Dennettia tripetala leaf extracts. It shows the linear relationship between the antioxidant activities and the concentration of the extracts from which the various IC50s and EC50 was extrapolated. The Dennetta tripetala extract had an IC50 lower than the standard antioxidant vitamins $\mathrm{C}$ and $\mathrm{E}$ showed (Methanol extract: $62.95 \mu \mathrm{g} / \mathrm{ml}$; Aqueous extract: $88.43 \mu \mathrm{g} / \mathrm{ml}$; Ascorbic Acid: $\quad 69.88 \mu \mathrm{g} / \mathrm{ml} ; \quad \alpha$-tocopherol: $\quad 65.46 \mu \mathrm{g} / \mathrm{ml}$ ) The trends shown in Fig. 1B for Nitric oxide radical scavenging activity showed that the standard antioxidant 
Table 3 Quantitative phytochemical screening of Dennettia tripetala leaves crude sample and extracts

\begin{tabular}{llll}
\hline Phytochemical & Crude leaf sample $(\mathbf{m g} / \mathbf{g})$ & Aqueous Extract(mg/g) & Methanol Extract(mg/g) \\
\hline Alkaloids & $4.84 \pm 0.23$ & $2.04 \pm 0.08$ & $3.14 \pm 0.30$ \\
Saponins & $0.38 \pm 0.00$ & $0.09 \pm 0.00$ & $0.26 \pm 0.03$ \\
Tannin & $3.82 \pm 0.26$ & $1.18 \pm 0.02$ & $2.86 \pm 0.63$ \\
Cardiac glycoside & $4.18 \pm 0.50$ & $2.98 \pm 0.04$ & $3.78 \pm 0.64$ \\
Reducing sugar & $3.04 \pm 0.37$ & $2.98 \pm 0.02$ & $3.13 \pm 0.00$ \\
Flavonoids & $6.09 \pm 0.02$ & $4.76 \pm 0.66$ & $5.89 \pm 0.32$ \\
Steroids & $0.36 \pm 0.02$ & $0.24 \pm 0.05$ & $0.11 \pm 0.05$ \\
\hline
\end{tabular}

All values are expressed as Mean \pm SD of three replicates

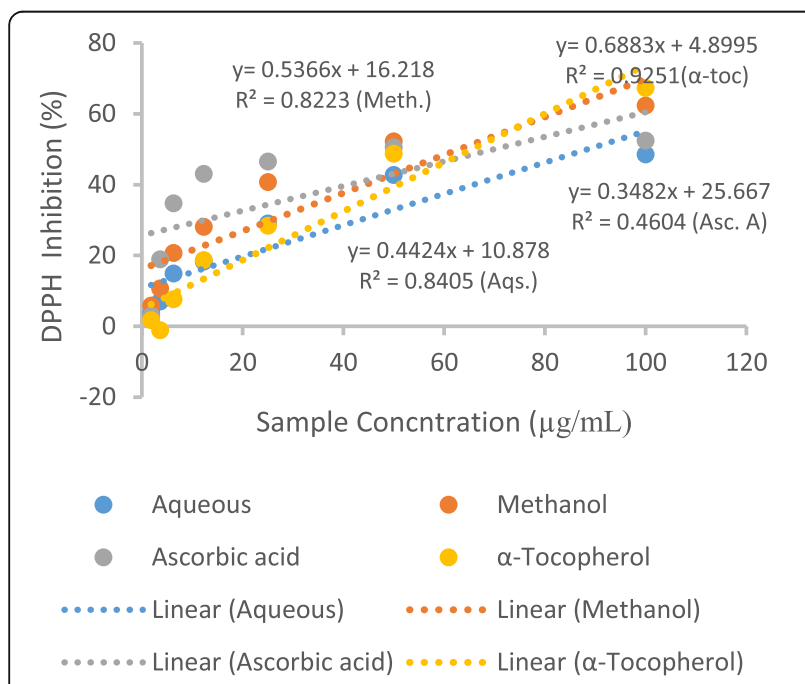

\section{A= DPPH Radical Scavenging activity}

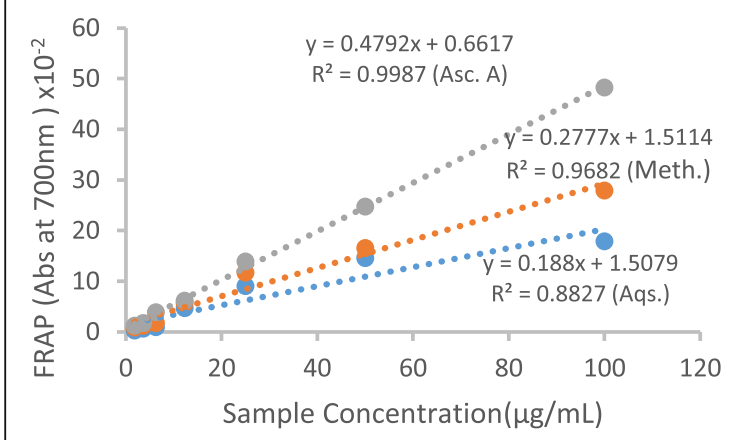

$$
\begin{aligned}
& \text { - Aqueous } \\
& \text { - Ascorbic Acid } \\
& \text { - Methanol } \\
& \text {....... Linear (Aqueous) } \\
& \text {....... Linear (Methanol) } \\
& \text {....... Linear (Ascorbic Acid) }
\end{aligned}
$$

\section{C = Ferric Reducing Antioxidant Power}

Fig. 1 In vitro antioxidant activities of Dennettia tripetala leaf extract
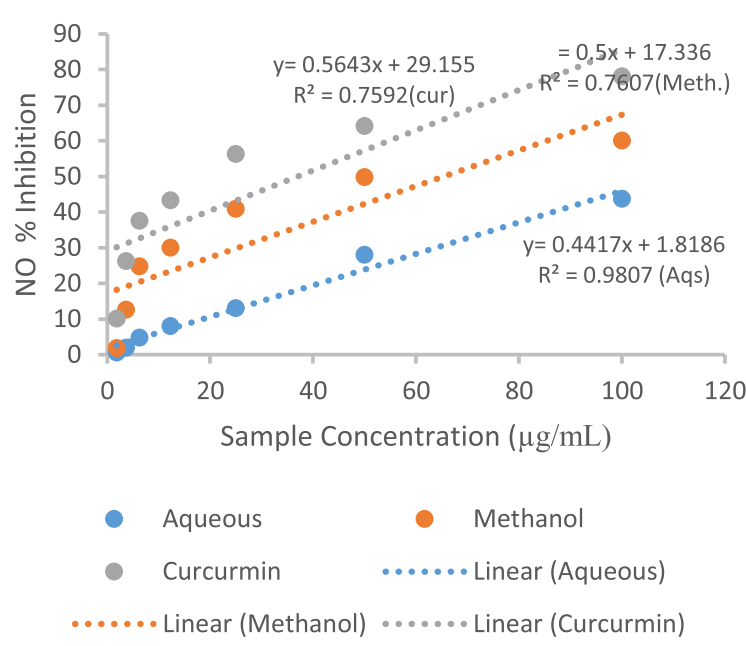

\section{$B=$ Nitric oxide Radical Scavenging Activity}

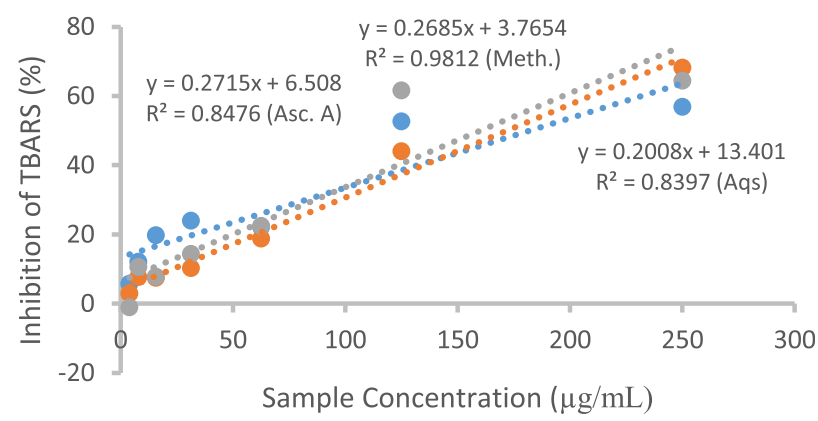

\footnotetext{
- Aqueous Extract

- Methanol Extract

- Ascorbic acid ....... Linear (Aqueous Extract )

....... Linear (Methanol Extract) ....... Linear (Ascorbic acid)
}

\section{D= Lipid Peroxidation (TBARS) Inhibition}


curcumin had the least followed by the methanol extract. The IC50 for Dennettia tripetala extracts relative to NO revealed (Methanolic extract: $65.32 \mu \mathrm{g} / \mathrm{ml}$; Aqs extract: $109.08 \mu \mathrm{g} / \mathrm{ml}$; Curcurmin: $36.94 \mu \mathrm{g} / \mathrm{ml})$. The Ferric reducing antioxidant power in Fig. $1 \mathrm{C}$ also showed similar trend observed for the $\mathrm{NO}^{-}$inhibition as the least value of the $50 \%$ effective dose (EC50) was observed in the standard antioxidant Vit. C $(102.90 \mu \mathrm{g} / \mathrm{ml})$ and was followed by the methanol extract $(174.61 \mu \mathrm{g} / \mathrm{ml})$ while the aqueous leave extract had the least effective dose $(257.94 \mu \mathrm{g} / \mathrm{ml})$. As in the $\mathrm{NO}$, the lipid peroxidation (TBARS) inhibition assay shown in Fig. 1D also revealed that the standard antioxidant ascorbic acid had a better activity as it had the least IC50 given at $(160.19 \mu \mathrm{g} / \mathrm{ml})$, this was followed by the methanolic extract which was $172.20 \mu \mathrm{g} / \mathrm{ml}$ ) and the aqueous extract which was $182.26 \mu \mathrm{g} / \mathrm{ml})$. Comparatively to the standard antioxidants, the methanolic extract had more antioxidant potency than the aqueous extract.

\section{Effect of Dennettia tripetala on weight gain}

Figure 2 presents the effect of Dennettia tripetala on body weight changes in Rats. It shows a relatively increased weight in rats administered $100 \mathrm{mg} / \mathrm{Kg}$ and 200 $\mathrm{mg} / \mathrm{Kg}$ body weight and relatively reduced weight occasioned by a negative weight gain potential in rats administered $500 \mathrm{mg} / \mathrm{Kg}$ bodyweight.

\section{Effect of Dennettia tripetala on liver function markers}

Figure 3 presents the activities of liver function markers in rats administered Dennettia tripetala methanolic extract and is indicative that comparative to control, there was a non-significant rise in serum and liver ALT in rats administered 100 and $200 \mathrm{mg} / \mathrm{Kg}$ body weight respectively but this increased in rats administered $500 \mathrm{mg} / \mathrm{Kg}$ body weight. Similar trends were observed in serum AST for $100 \mathrm{mg} / \mathrm{Kg}$ but increase were observed in 200 $\mathrm{mg} / \mathrm{Kg}$ and $500 \mathrm{mg} / \mathrm{Kg}$ respectively. ALP activities increased in serum for $100 \mathrm{mg} / \mathrm{Kg}$ and $500 \mathrm{mg} / \mathrm{Kg}$ but not for $200 \mathrm{mg} / \mathrm{Kg}$ relative to control while there were observed rise in liver ALP for all test groups relative to control.

Figure 4 presents the data on changes in protein profile of rats following treatment with Dennettia tripetala methanolic extract. It shows a non-significant difference across all experimental groups on serum total protein profile while the liver only showed a significant decrease in the $200 \mathrm{mg} / \mathrm{Kg}$ group relative to control. The albumin levels on the other hand showed a significant decrease in the serum of the $200 \mathrm{mg} / \mathrm{Kg}$ group while all groups showed no significant difference in the liver relative to control.

\section{Effect of Dennettia tripetala on renal function markers}

Figure 5 presents the effect of Dennettia tripetala methanolic extract on urea and creatinine levels in the serum and kidney. There were observed significant rise in serum urea in the $200 \mathrm{mg} / \mathrm{Kg}$ and $500 \mathrm{mg} / \mathrm{Kg}$ body weight relative to control while kidney urea was not significantly affected compared to control but on a dose comparison was reduced in the $500 \mathrm{mg} / \mathrm{Kg}$ body weight relative to the $100 \mathrm{mg} / \mathrm{Kg}$ dose. Serum creatinine levels were observed to reduce significantly in the $100 \mathrm{mg} / \mathrm{Kg}$ group but increased significantly in the $200 \mathrm{mg} / \mathrm{Kg}$ and $500 \mathrm{mg} / \mathrm{Kg}$ group with respect to control. The kidney creatinine decreased significantly in the $200 \mathrm{mg} / \mathrm{Kg}$ group and increased in the $500 \mathrm{mg} / \mathrm{Kg}$ group compared to control group.

Table 4 presents the effect of Dennettia tripetala leaf extract on serum electrolytes. This is indicative of a non-significant change across all experimental groups for $\mathrm{K}^{+}$while the only significant rise observed for $\mathrm{Na}^{+}$ and $\mathrm{Ca}^{+}$were for the $500 \mathrm{mg} / \mathrm{Kg}$ group. Significant drop in $\mathrm{Cl}^{-}$was also observed for $500 \mathrm{mg} / \mathrm{Kg}$ group and the other groups remained non-significant compared to control. The bicarbonate ion was observed to have no

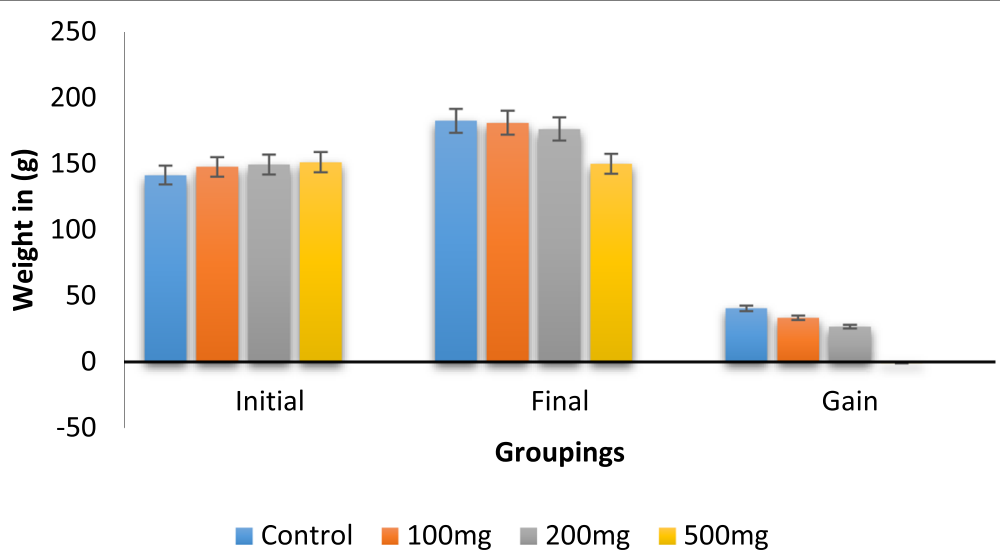

Fig. 2 Effect of Dennetia tripetalla Extract on Animal Weight 


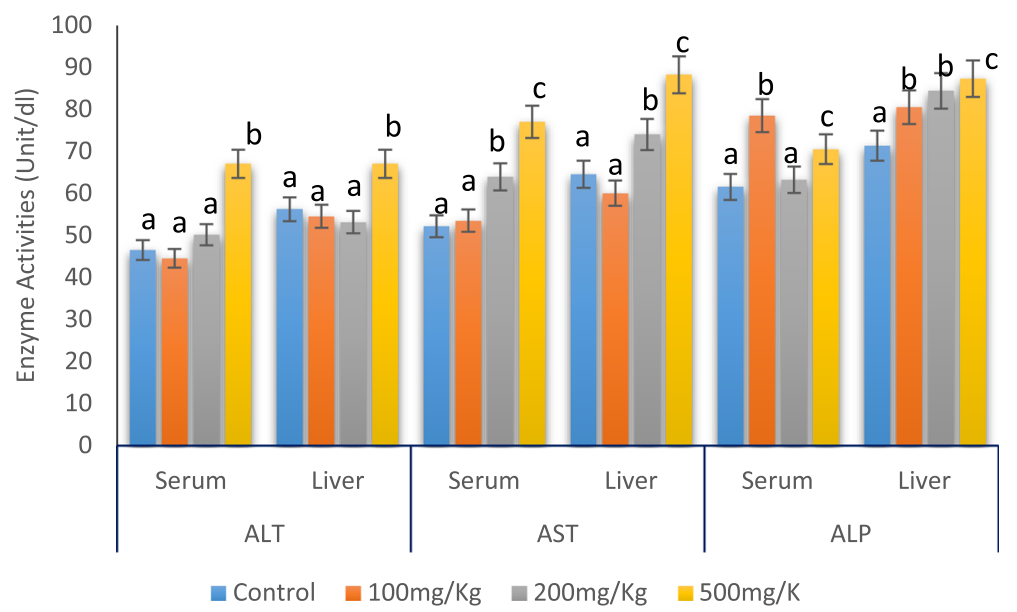

Fig. 3 Effect of Dennettia tripetala on activities of serum and tissue Liver function markers (ALT, AST, ALP)

significant change compared to control but reduced in the $100 \mathrm{mg} / \mathrm{Kg}$ group compared to 200 and $500(\mathrm{mg} / \mathrm{kg})$ groups respectively.

Table 5 presents the effects of Dennettia tripetala methanolic leaf extract on kidney electrolyte profile and indicates that there was no significant change in $\mathrm{K}^{+}$of the $100 \mathrm{mg} / \mathrm{Kg}$ and $200 \mathrm{mg} / \mathrm{Kg}$ groups compared to control but this was elevated in the $500 \mathrm{mg} / \mathrm{Kg}$ group. Likewise, no significant changes were observed in $\mathrm{Na}^{+}$in the $100 \mathrm{mg} / \mathrm{Kg}$ and $500 \mathrm{mg} / \mathrm{Kg}$ while reduction was observed in the $200 \mathrm{mg} / \mathrm{Kg}$ relative to control. $\mathrm{Ca}^{+}$had no significant change in the $100 \mathrm{mg} / \mathrm{Kg}$ group but increased in the $200 \mathrm{mg} / \mathrm{Kg}$ and $500 \mathrm{mg} / \mathrm{Kg}$ respectively compared to control. The $\mathrm{Cl}^{-}$levels in the kidney were reportedly not significantly increased for the $100 \mathrm{mg} / \mathrm{Kg}$ group as well as not significantly reduced for the $200 \mathrm{mg} / \mathrm{Kg}$ group but was significantly reduced for the $500 \mathrm{mg} / \mathrm{Kg}$ group relative to control. Kidney bicarbonate had no significant change across groups $100 \mathrm{mg} / \mathrm{Kg}$ and $500 \mathrm{mg} / \mathrm{Kg}$ but this was significantly reduced in the $200 \mathrm{mg} / \mathrm{Kg}$ group compared to control.

\section{Effect of Dennettia tripetala extract on oxidative stress and antioxidant defense system}

Figure 6 presents the results of lipid peroxidation and antioxidant profile of rats following Dennettia tripetala methanolic extract administration. The MDA levels were reported to significantly increase in liver tissues across the $200 \mathrm{mg} / \mathrm{Kg}$ and $500 \mathrm{mg} / \mathrm{Kg}$ group and reduced in the $100 \mathrm{mg} / \mathrm{Kg}$ group compared to control. Kidney tissue indicates a non-significant difference for the $100 \mathrm{mg} / \mathrm{Kg}$ and significant increase for the $200 \mathrm{mg} / \mathrm{Kg}$ and $500 \mathrm{mg} /$ $\mathrm{Kg}$ groups. Heart tissues only showed a significant rise in the $500 \mathrm{mg} / \mathrm{Kg}$ group and no significant difference in other groups relative to control. Testes indicated no significant change in all experimental groups. SOD

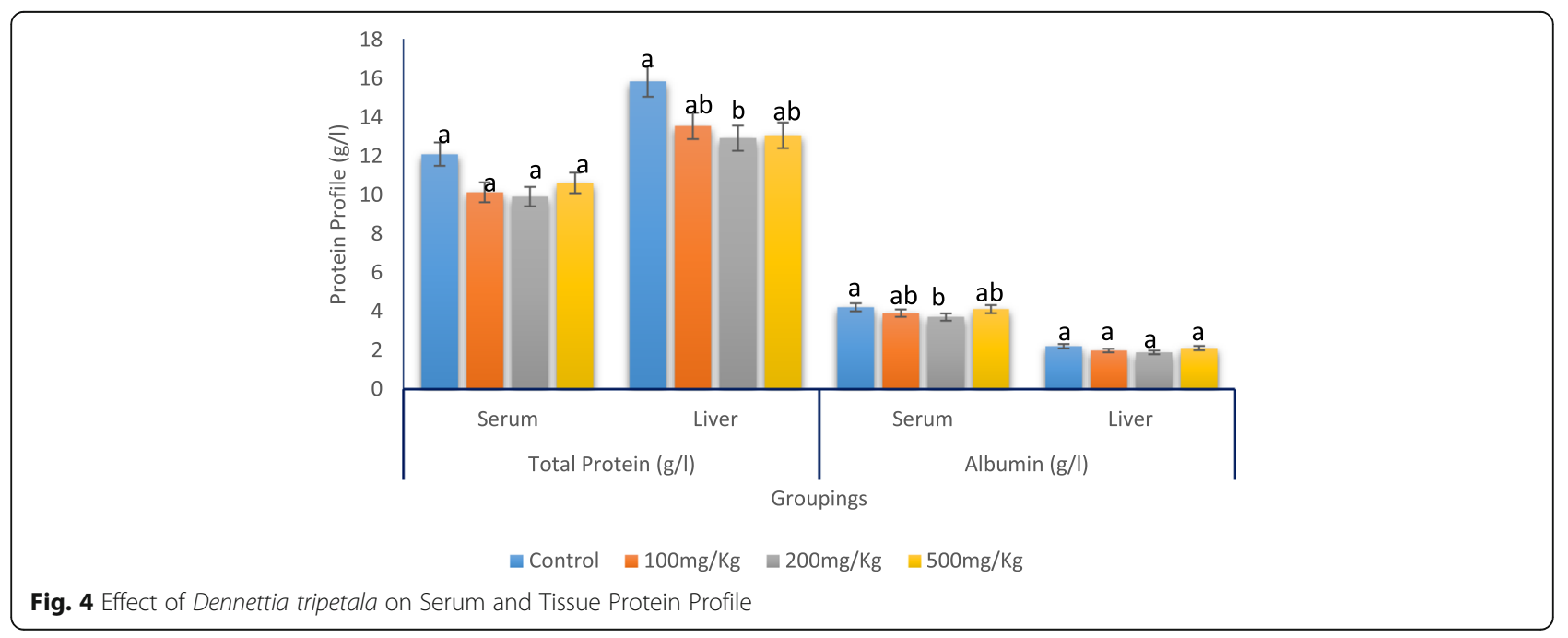




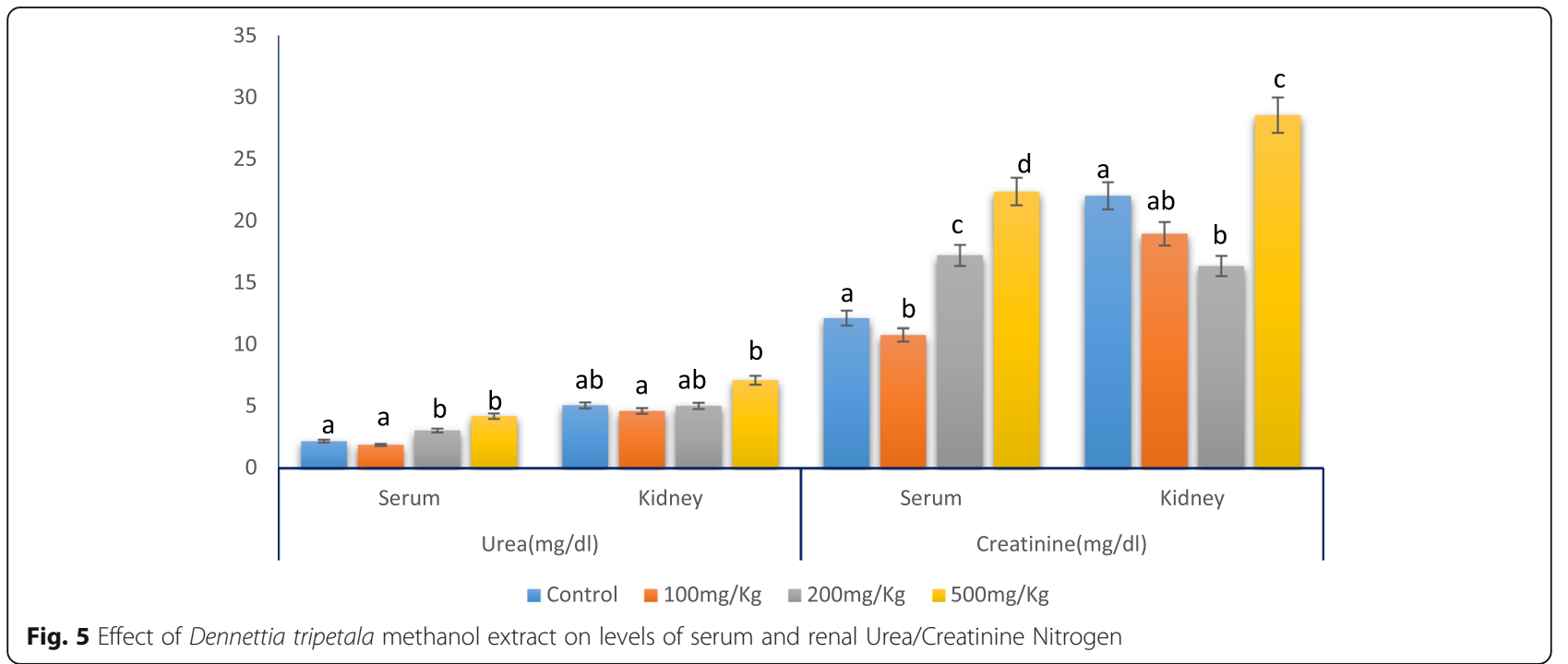

activities significantly increased in the liver only for the $500 \mathrm{mg} / \mathrm{Kg}$ group relative to control and in the kidney, heart and testes for the $200 \mathrm{mg} / \mathrm{Kg}$ and $500 \mathrm{mg} / \mathrm{K} \mathrm{Cg}$ groups respectively with respect to control. Catalase enzyme activities rose significantly across all test groups in the liver compared to control but reduced in the kidney while increasing in the heart and testes for the $200 \mathrm{mg} / \mathrm{Kg}$ and $500 \mathrm{mg} / \mathrm{Kg}$ respectively compared to control. Kidney, heart and testes GSH levels had no significant changes across all experimental groups while liver GSH was significantly depleted in the $500 \mathrm{mg} / \mathrm{Kg}$ group relative to all other groups. Glutathione peroxidase (GPx) enzyme activities were significant for the liver relative to control at the $200 \mathrm{mg} / \mathrm{Kg}$ and $500 \mathrm{mg} /$ $\mathrm{Kg}$ respectively while the kidney showed no significant change across all groups. Heart GPx activities were only significant at $200 \mathrm{mg} / \mathrm{Kg}$ and $100 \mathrm{mg} / \mathrm{kg}$, $200 \mathrm{mg} / \mathrm{kg}$ and $500 \mathrm{mg} / \mathrm{kg}$ showed significant rise relative to control in the testes. The activities of Glutathione-S-Transferase (GST) showed no significant change across all tissues and all doses of exposure of Dennettia tripetala methanolic extract.

Bars in the same organ showing different alphabet superscripts indicates they are significantly different $(p<0.05)$.

\section{Effect of Dennettia tripetala on liver histology}

Liver histology results is indicative of no deleterious observations in control rats and those administered 100 $\mathrm{mg} / \mathrm{kg}$ and $200 \mathrm{mg} / \mathrm{kg}$ as there were very clear hepatic cells (A) and sinusoids emanating from the central vein (B). Rats treated with $500 \mathrm{mg} / \mathrm{Kg}$ presents gradual ballooning of the hepatic cells and veins $(\mathrm{C})$ while the rats treated with $1000 \mathrm{mg} / \mathrm{Kg}$ shows very visible signs of hepatic necrosis (D) and degeneration of the central vein (E). Findings observed in the liver of experimental animals administered $500 \mathrm{mg} / \mathrm{kg}$ and $1000 \mathrm{mg} / \mathrm{kg}$ of Dennetia tripetalla revealed marked distortion of the liver architecture.

\section{Discussions}

The importance of plant materials as major sources of active medicinal substances needed for the mitigation of several medical conditions abounds in literature [5, 8, $37,38]$. The present study revealed the presence of several phytochemicals such as alkaloids, saponins, tannins, cardiac glycosides, reducing sugars, flavonoids and steroids in the leaves of Dennetia tripetalla extracts via qualitative determinations and was further confirmed using quantitative determinations. These observations

Table 4 Effects of Dennettia tripetala methanol leaf extract on Serum Electrolyte Profile

\begin{tabular}{llllll}
\hline Groups & $\mathbf{K}^{+}(\mathbf{M e q} / \mathbf{L})$ & $\begin{array}{l}\mathbf{N a}^{+} \\
(\mathbf{M e q} / \mathbf{L})\end{array}$ & $\begin{array}{l}\mathrm{Ca}^{+} \\
(\mathbf{M e q} / \mathbf{L})\end{array}$ & $\begin{array}{l}\mathrm{Cl}^{-} \\
(\mathbf{M e q} / \mathbf{L})\end{array}$ & $\begin{array}{l}\mathrm{HCO}^{-} \\
(\mathbf{M e q} / \mathbf{L})\end{array}$ \\
\hline Control & $5.07 \pm 0.04^{\mathrm{a}}$ & $62.44 \pm 1.18^{\mathrm{a}}$ & $6.27 \pm 1.02^{\mathrm{a}}$ & $11.16 \pm 0.27^{\mathrm{a}}$ & $2.08 \pm 0.62^{\mathrm{ab}}$ \\
$100 \mathrm{mg} / \mathrm{Kg}$ & $4.98 \pm 0.01^{\mathrm{a}}$ & $60.08 \pm 0.62^{\mathrm{a}}$ & $8.08 \pm 2.22^{\mathrm{ab}}$ & $11.02 \pm 0.04^{\mathrm{a}}$ & $1.88 \pm 0.06^{\mathrm{a}}$ \\
$200 \mathrm{mg} / \mathrm{Kg}$ & $5.46 \pm 0.06^{\mathrm{a}}$ & $58.22 \pm 2.44^{\mathrm{a}}$ & $6.40 \pm 1.01^{\mathrm{a}}$ & $10.06 \pm 0.11^{\mathrm{a}}$ & $2.80 \pm 0.77^{\mathrm{b}}$ \\
$500 \mathrm{mg} / \mathrm{Kg}$ & $5.98 \pm 0.06^{\mathrm{a}}$ & $68.22 \pm 0.66^{\mathrm{b}}$ & $9.98 \pm 0.06^{\mathrm{b}}$ & $8.17 \pm 0.0 .85^{\mathrm{b}}$ & $2.18 \pm 0.76^{\mathrm{ab}}$ \\
\hline
\end{tabular}

All values are expressed as Mean \pm SD values followed by a different alphabet superscript in the same column indicate a significant difference 
Table 5 Effects of Dennettia tripetala methanol leaf extract on Kidney Electrolyte Profile

\begin{tabular}{llllll}
\hline Groups & $\mathbf{K}^{+}$(Meq/L) & $\begin{array}{l}\mathbf{N a}^{+} \\
(\mathbf{M e q} / \mathbf{L})\end{array}$ & $\begin{array}{l}\mathbf{C a}^{+} \\
(\mathbf{M e q} / \mathbf{L})\end{array}$ & $\begin{array}{l}\mathrm{Cl}^{-} \\
(\mathbf{M e q} / \mathbf{L})\end{array}$ & $\begin{array}{l}\mathrm{HCO}^{-} \\
(\mathbf{M e q} / \mathbf{L})\end{array}$ \\
\hline Control & $7.27 \pm 0.14^{\mathrm{ab}}$ & $72.07 \pm 0.08^{\mathrm{a}}$ & $5.07 \pm 0.04^{\mathrm{ab}}$ & $9.62 \pm 0.70^{\mathrm{ab}}$ & $3.81 \pm 0.78^{\mathrm{a}}$ \\
$100 \mathrm{mg} / \mathrm{Kg}$ & $6.82 \pm 0.18^{\mathrm{a}}$ & $69.08 \pm 0.02^{\mathrm{a}}$ & $4.98 \pm 0.01^{\mathrm{a}}$ & $10.20 \pm 1.40^{\mathrm{a}}$ & $2.99 \pm 0.63^{\mathrm{ab}}$ \\
$200 \mathrm{mg} / \mathrm{Kg}$ & $8.64 \pm 0.01^{\mathrm{bc}}$ & $58.22 \pm 0.02^{\mathrm{b}}$ & $7.46 \pm 0.06^{\mathrm{b}}$ & $8.26 \pm 0.01^{\mathrm{bc}}$ & $2.88 \pm 0.07^{\mathrm{b}}$ \\
$500 \mathrm{mg} / \mathrm{Kg}$ & $9.82 \pm 0.26^{\mathrm{c}}$ & $74.22 \pm 0.07^{\mathrm{a}}$ & $11.11 \pm 1.24^{\mathrm{c}}$ & $7.98 \pm 0.0 .02^{\mathrm{c}}$ & $3.08 \pm 0.96^{\mathrm{ab}}$ \\
\hline
\end{tabular}

All values are expressed as Mean \pm SD values followed by a different alphabet superscript in the same column indicate a significant difference

are in tandem with the reports on the fruits of Dennetia tripetalla by Omage et al., [39] as well as previous reports [16] on the presence of polyphenols, flavonoids and saponins in the leaf of Dennetia tripetalla ethanolic extracts. The medical importance of alkaloids have been reported to include drug synthesis especially analgesics, antibiotics and antispasmodics [16, 40]. Likewise, saponins have been noted to be responsible for the reduction of hypercholesterolemia as well as serving as emulsifiers and expectorants [1, 41, 42]. Saponins have also been previously reported to possess wound healing properties as well as the ability to induce hemolysis while acting as an antifungal agent $[43,44]$. The presence of flavonoids and polyphenols in plants often confers on the plant with antioxidant properties and are often the reason while most plants are explored for their medicinal capabilities. Flavonoids and polyphenols are reported to possess anticancer properties and have the ability to reduce inflammation as well as possess antimalarial, antiviral, antibacterial and inhibition of hyper cholesterol synthesis [45-47].

The Results of the in vitro antioxidant properties of the aqueous and methanolic plant leaf extracts (Fig. 1) are indicative that the plant extracts possesses antioxidant properties comparable to standard antioxidants such as curcumin, vitamins $C$ and $E$. This is owing to their abilities to scavenge DPPH and $\mathrm{NO}^{-}$free radicals, possession of good ferric reducing antioxidant power at low concentrations as shown by the IC50 and EC50 values and compares favourably with ascorbic acid in the inhibition of lipid peroxidation. These properties were also previously reported in the plants fruit ethanolic and aqueous fruit extract [39]. There is no doubt that these properties may have arisen owing to the high level of phytochemicals earlier reported in this study. Comparatively, the methanol extract possess a better antioxidant property than the aqueous extract. This was exhibited when test indices were compared to standard antioxidant vitamin $C$, vitamin $E$ and curcumin and may be linked to the fact that methanol had a much more significant capacity to extract the phytochemicals inherent in the plant. This assertion is supported by Onakhurefe et al., [42] who reported that most substances possessing high levels of hydrophobicity will dissolve better in higher polar compounds. Therefore, the result of this study is indicative that the Dennettia tripetala leaf extracts possesses significant high antioxidant properties that are comparable with standard vitamin $\mathrm{C}$ and $\mathrm{E}$ and the previously reported antioxidant property of the ethanolic and aqueous fruit extracts [39].

Studies have reported the use of Dennettia tripetala leaf for the treatment of diarrhea, cough and fever among locals in Nigeria $[9,16,38]$ yet no existing study have evaluated the toxicity profile of this leaf. In the current study, we evaluated the toxicity profile of Dennettia tripetala by subjecting it to acute and chronic toxicity study. Our result revealed muscle weakness and mood alterations in the experimental animals administered $1500 \mathrm{mg} / \mathrm{kg}$ and $2000 \mathrm{mg} / \mathrm{kg}$ body weight of Dennettia tripetala It is important to note that the results from the acute toxicity study, though revealed no death of animals at the highest dose of $2000 \mathrm{mg} / \mathrm{Kg}$ within 48 $\mathrm{h}$, the purported moody and weakness experienced in rats administered with $1500 \mathrm{mg} / \mathrm{Kg}$ and $2000 \mathrm{mg} / \mathrm{Kg}$ plant extracts gives an insight into the possible toxicity potentials of the plant leaf. This was corroborated by the elevation of serum ALT and AST activities as well as the reduction in haematological parameters within $48 \mathrm{~h}$ at these doses. These observations are in consonance with earlier reports who noted that alterations in these parameters are among the first line of responses to toxicity $[30,48]$.

Also, the reported death of rats administered $1000 \mathrm{mg} /$ $\mathrm{Kg}$ and the eventual reduction in weight by animals administered $500 \mathrm{mg} / \mathrm{Kg}$ of the plant extracts following a prolonged period of administration gives further credence to our claims of the possible toxicity potential of the plant leaves. Body weight loss has been previously established as a significant early marker and responses to toxicity potentials of substances especially as it relates to drugs $[49,50]$. The observed further significant elevation in liver function enzymes especially as it relates to ALT, AST and ALP at $500 \mathrm{mg} / \mathrm{Kg}$ dose relative to control (Fig. 3) may be indicative of a possible compromise on the liver tissue, which may have necessitated the increased leakage of these enzymes into the blood [51, 52]. A look at the serum and hepatic protein profile of rats administered the Dennettia tripetala methanolic leaf 


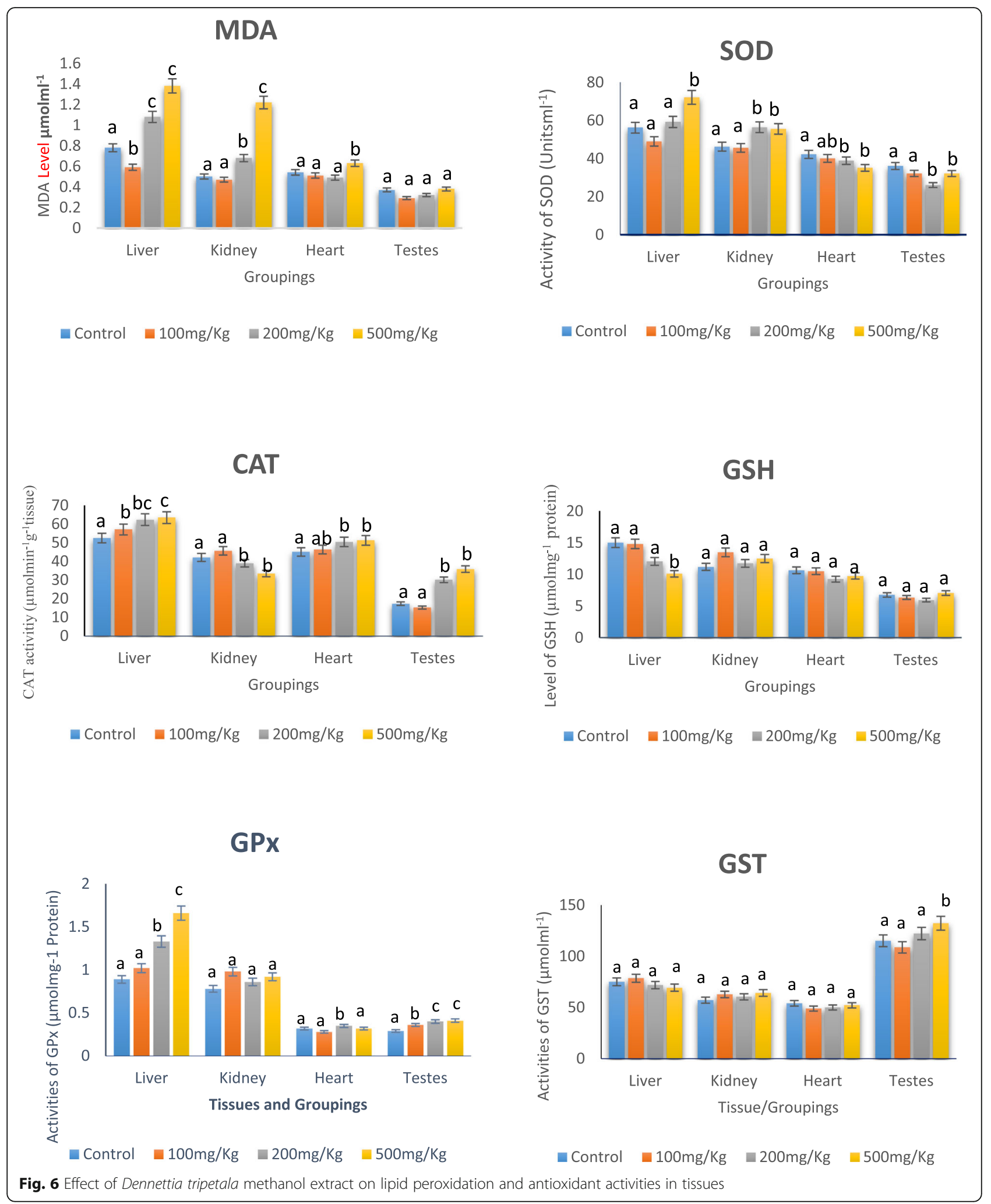

extract (Fig. 4) is indicative of a non-alteration of protein synthesis at all doses. The stability of these parameters may also give us an insight into a possible beneficial contribution of the plant extract to protein synthesis. The ability of plant extracts to significantly contribute to the stability of endoplasmic reticulum and the mediated 
improved hepatic protein synthesis has been previously reported [51, 53]. Also, Omage et al [39] reported that the administration of the ethanolic and aqueous fruit extracts of Dennettia tripetala did not alter the serum and hepatic protein profile of rats at a dose up to $1000 \mathrm{mg} /$ $\mathrm{Kg}$ body weight. One of the clinical significances of albumin in the blood is that it acts as a transporter for drugs and helps in the prevention of leakage of significant blood vessels [53]. Hence the ability of the Dennettia tripetala leaf extract to promote their synthesis may be one of the beneficial effects inherent in the plant which people who use them for treatment of ailments may have continually benefited from.

The kidney is a major organ of metabolic significance owing to their role in the filtration process of toxicants and absorption of essential nutrients and minerals from the blood [18, 54]. The compromise in structure and function of the kidney has a high level of implication in human and animal health. The result in the present study is indicative of a significant elevation of serum urea and creatinine (Fig. 5) at doses of $200 \mathrm{mg} / \mathrm{Kg}$ and $500 \mathrm{mg} / \mathrm{Kg}$ may also be implicative of a possible renal compromise as their elevation in the serum has been well documented as significant markers of kidney malfunction occasioned by loss of glomeruli filtration [18, 54]. This assertion is also suggestive of the fact that the alleged rise in kidney urea and creatinine is as a result of retention of these toxic substances which ought to be filtered out for excretion so as to promote proper renal function. The electrolytes which are another significant set of indicators for kidney functions were also found to be altered mostly in rats administered the $500 \mathrm{mg} / \mathrm{Kg}$ dose of the Dennettia tripetala leaf extracts. Although there were no significant alterations in serum potassium ions, a significant rise in serum levels of sodium and calcium as well as reduction in serum chloride ions (Table 4) gives cause for worry. The elevation in serum calcium ions is suggestive of a possible disruption in certain ion pumps and trans-membrane ATPases within the liver and kidney [18, 37, 55]. In another development, changes due to rise in serum sodium levels and reductions in chloride have implications for monitoring heart complications, decreased blood circulations and acidbase abnormalities which contributes significantly to the mal-absorption of these electrolytes within the kidney $[56,57]$. It is interesting to note that findings in this study agree with previous studies on the ability of Aframomium sceptrum and Aframomium maligueta extracts to contribute significantly in the elevation of serum and renal sodium ions in rat species $[54,55]$. Comparatively, at the dose of $100 \mathrm{mg} / \mathrm{Kg}$ and $200 \mathrm{mg} / \mathrm{Kg}$ it was observed that most renal indices were relatively stable when compared to control implying that these doses may have some element of significant beneficial potentials to the experimental animals. This further brings to fore earlier suggestions [18] that certain plant substances may hold beneficial properties, when administered in the right dose.

Also studied in this investigation is the antioxidant response mechanisms to a prolonged administration of varied doses of methanol extract of Dennetia tripetalla which showed rise in MDA (Fig. 6) at doses of the 200 $\mathrm{mg} / \mathrm{Kg}$ and $500 \mathrm{mg} / \mathrm{Kg}$ in the liver and kidney while heart tissues were only elevated in the $500 \mathrm{mg} / \mathrm{Kg}$ group. The evidential rise in lipid peroxidation further substantiates our claim of a possible toxic potential possessed by the plant leaf extract at these doses (200 \& 500) mg/ $\mathrm{Kg}$ as rise in lipid peroxidation is a known marker for breakdown in membrane lipids and increased oxidative stress $[48,58,59]$. Rising lipid peroxidation is often predicated by disruption of the antioxidant defense systems and in some other cases induces the expression of several antioxidant potentials that contributes to the clearance of oxidative radicals arising from peroxidation of lipids [60, 61]. As expected, there were significant rises in the antioxidant enzymes superoxide dismutase and catalase which are known scavengers of the superoxide anion $\left(\mathrm{O}_{2}{ }^{-}\right)$and hydrogen peroxides $\left(\mathrm{H}_{2} \mathrm{O}_{2}\right)$ converting them to less dangerous species. Although no significant rise were observed in the non-enzymatic antioxidant (GSH) (Fig. 6) across all tissues except in the liver of rats administered $500 \mathrm{mg} / \mathrm{Kg}$ body weight, rise in GPx activities at doses of (200 \& 500) $\mathrm{mg} / \mathrm{kg}$ in the liver and testes may be indicative of complementary mechanism to support the clearance of rising peroxides within these tissues. This is simply so because the enzyme GPx together with SOD have been known to work in tandem with the catalase enzyme for clearance of oxidative potentials within tissues [62, 63]. Thus observed rise in these enzymes may have occurred in response to immunity boost of the animals or may have been as a result of the need to rise against the toxic effects of the plants in the animals. These claims and submissions are in agreement with [39] which also reported increased hepatic and renal SOD and catalase in rats administered Dennettia tripetala fruit aqueous and ethanol extracts.

In furtherance of our hypothesis, the histopathological analysis of the liver revealed a disruption in the hepatic architecture occasioned by hepatic necrosis for rats administered $1000 \mathrm{mg} / \mathrm{Kg}$ body weight of the plant extracts (Fig. 7) after sacrifice on day 18 of the experiment. Also, the gradual ballooning of the hepatic veins and sinusoids in the $500 \mathrm{mg} / \mathrm{Kg}$ group (Fig. 7) confirms our claim of the toxic potential of this plant at this dose. The nonpresence of necrosis in the rats administered $200 \mathrm{mg} / \mathrm{Kg}$ and $100 \mathrm{mg} / \mathrm{Kg}$ as compared to control may be indicative that the plant extracts is well tolerated at these doses. Although the exact mechanisms by which this 


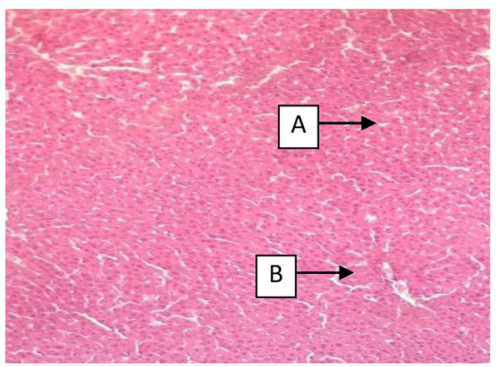

Control

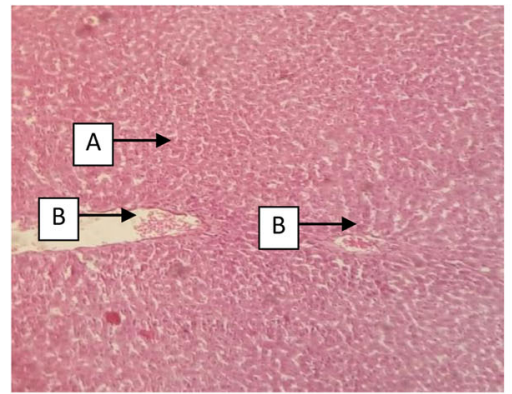

$200 \mathrm{mg} / \mathrm{Kg}$

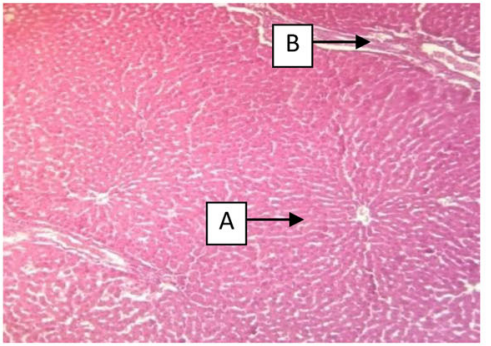

$100 \mathrm{mg} / \mathrm{Kg}$

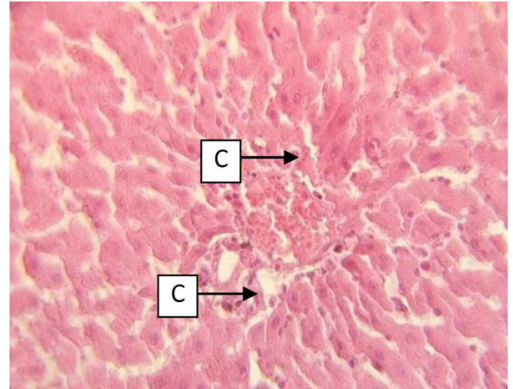

$500 \mathrm{mg} / \mathrm{Kg}$

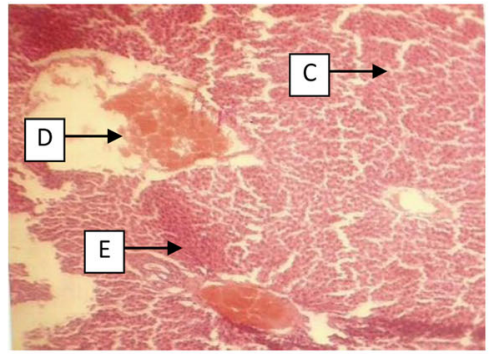

$1000 \mathrm{mg} / \mathrm{Kg}$

Fig. 7 Effect of Dennetia tripetalla methanol extract on Liver Architecture $(H \& E \times 100)$

plant extract may cause liver toxicity is unknown, it is believed that the liver tissue is prone to drug induced toxicity due to its high capacity in metabolism and the presence of xenobiotics in the liver [64].

\section{Conclusion}

The current study is suggestive that the leaf extract of Dennettia tripetala possesses significant phytochemicals of medical interest as well as antioxidant properties comparable to standard antioxidants vitamins $\mathrm{C}$ and $\mathrm{E}$ and curcumin. However, they stand to possess levels of toxic properties in rats when administered at a dose above $200 \mathrm{mg} / \mathrm{Kg}$ over a prolonged period of time and $1500 \mathrm{mg} / \mathrm{Kg}$ within a short period of about $48 \mathrm{~h}$ hence have the capacity to alter several organ functions related to metabolic stability. At this dose $(200 \mathrm{mg} / \mathrm{Kg})$ also, it could be said to have the ability to induce several indices of antioxidant defense within the system. The implication of this to its ethno-pharmacological application to the treatment of ailments is that its functionality is greatly dependent on a dose response function and is recommended that when used, it should not be used excessively or indiscriminately abused so as not to elicit its toxic properties. It could suffix therefore to say based on our study that the safe dose of Dennettia tripetala is at $200 \mathrm{mg} / \mathrm{kg}$ body weight for rats.

\section{Prospects for further studies}

The significance of the oxidized and reduced glutathione (GSH/GSSG) ratio in understanding responses to oxidative stress and different health related conditions in mammals has been well established in both in vitro and 
in vivo studies [65-68]. Also the use of messenger RNA (mRNA) expression of different tissue antioxidants for confirmatory purposes and a better mechanistic understanding of the trends in antioxidant enzyme activities has been established [69-71]. Although we did not consider this aspect in the current study, there is no doubt that our study being a preliminary study have established the basic data for toxicological understanding of the effects of methanolic leaf extracts of Dennettia tripetala. We however hope to consider these factors in follow up studies using this plant so as to further substantiate the claims made by us.

\section{Abbreviations}

TBARS: Thiobarbitoric Acid Reactive Substance; MDA: Malondialdehyde; PUFA: Polyunsaturated Fatty Acid; GSH: Reduced Glutathione; SOD: Superoxide Dismutase; CAT: Catalase; ANOVA: Analysis of Variance; AST: Aspartate amino transferase; ALT: Alanine amino transferase;

GST: Glutathione-S-transferas; GPx: Glutathione peroxidase

\section{Supplementary Information}

The online version contains supplementary material available at https://doi. org/10.1186/s40816-021-00298-w.

\section{Additional file 1}

\section{Authors' contributions}

Authors JCM and PCI designed and conceived the study. Authors GRK and $\mathrm{PCl}$ carried out the animal care and laboratory analysis under the supervision of JCM. Literature search and data analysis was carried out by authors RNI, JCO and UE. Initial manuscript draft was carried out by authors PCI and JCM. All authors read and approved of the contents in the final draft.

\section{Funding}

There was no specific funding received for this research.

\section{Availability of data and materials}

Data used to support the findings of this study are included within the manuscript.

\section{Declarations}

Ethics approval and consent to participate

Not applicable.

\section{Consent for publication}

Not applicable.

\section{Competing interests}

The authors declare that they have no competing interests.

\section{Author details \\ ${ }^{1}$ Department of Biochemistry, Faculty of Science Delta State University, Abraka, Nigeria. ${ }^{2}$ Department of Medical Biochemistry, Faculty of Basic Medical Sciences Delta State University, Abraka, Nigeria. ${ }^{3}$ Department of Biochemistry, Faculty of Life Sciences, University of Benin, Benin City, Nigeria. ${ }^{4}$ Department of Human Anatomy, Faculty of Basic Medical Sciences, University of Port Harcourt, Port Harcourt, Nigeria.}

Received: 2 January 2021 Accepted: 23 June 2021

Published online: 05 July 2021

\section{References}

1. Edeoga HO, Okwu DE, Mbaebie BO. Phytochemical constituents of some Nigerian medicinal plants. Afr J Biotechnol. 2005;4(7):685-8. https://doi.org/1 $0.5897 / \mathrm{AJB}$.
2. Idu M, Omogbai EKl, Aghimien GE, Amaechina F, Timothy O, Omonigho SE. Preliminary phytochemistry, antimicrobial properties and acute toxicity of Stachytarphetajamaicensis (L) Vahl. Leaves. Trends Med Res. 2007;2:193-8.

3. Farnsworth NR, Akerele RO, Bingel AS, Soejarto DD, Guo Z. Medicinal Plants in Therapy. Bull WHO. 1985;63:965-81.

4. Dias DA, Urban S, Roessner U. A historical overview of natural products in drug discovery. Metabolites. 2012;2(2):303-36 https://doi.org/10.3390/meta bo2020303.

5. WHO. Traditional Medicine Growing Needs and Potential - WHO Policy Perspectives on Medicines. 2002; May Available on https://apps.who.int/ medicinedocs/en/d/Js2293e/

6. Okwu DE, Morah FNI. Mineral and nutritive value of Dennettia tripetala fruits Fruits. 2004;59(6):437-42. https://doi.org/10.1051/fruits:2005006.

7. Timothy CO, Okere CO. Effect of Dennettia tripetela (MMIMI) seed intake on the IOP of normotensive Emmetropic Nigerian Igbos. J Nigr Optometric Assoc. 2008;14(1):14-7. https://doi.org/10.4314/jnoa.v14i1.55583.

8. Akabueze KO, Idu M, Erhabor JO, Timothy O. Antimicrobial and phytochemical attributes of Dennettia tripetala f. baker root and bark extracts. J Microbiol Biotech Food Sci. 2016:5(4):297-300.

9. Iseghohi SO. A review of the uses and medicinal properties of Dennettiatripetala (Pepperfruit). Med Sci. 2015;3(4):104-11. https://doi.org/1 0.3390/medsci3040104

10. Aderogba MA, Akinkunmi EO, Mabusela WT. Anti-oxidant and antimicrobial activities of flavonoid glycosides from Dennettia tripetala $\mathrm{G}$. baker leaf extract. Niger J Nat Prod Med. 2011;15:49-52.

11. Adedayo BC, Oboh G, Akindahunsi AA. Changes in the total phenol content and antioxidant properties of pepper fruit (Dennettiatripetala) with ripening. Afr J Food Sci. 2010:4:403-9.

12. Dike MC. Proximate, phytochemical and nutrient compositions of some fruits, seeds and leaves of some species at Umudike, Nigeria. ARPN J Agric Biosci. 2010;5:7-16.

13. Oyemitan IA, Iwalewa EO, Akanmu MA, Olugbade TA. Antinociceptive and anti-inflammatory effects of essential oil of Dennettia tripetala G. baker (Annonaceae) in rodents. Afri J Tradit Complement Altern Med. 2008:5:35562.

14. Ejechi BO, Nwafor OE, Okoko FJ. Growth inhibition of tomato-rot fungi by phenolic acidsand essential oil extracts of pepper fruit. Food Res Int. 1999; 32(6):395-9. https://doi.org/10.1016/S0963-9969(99)00057-5.

15. Anaga AO, Asuzu IU. Glucose uptake-enhancing activity of the ethyl acetate extract of Dennettiatripetala in 3T3-L1 adipocytes. J Complement Integr Med. 2011;8(1). https://doi.org/10.2202/1553_3840.1438.

16. Osuagwu GGE, Eme CF. The phytochemical composition and antimicrobial activity of Dialiumguineensevitexdoniana and Dennettiatripetalaleaves. Asian Jat Appl Sci. 2013;2(3):69-81.

17. Ebana RUB, Asamudo NU, Etok CA, Edet UO, Onyebuisi CS. Phytochemical screening, nutrient analysis and antimicrobial activity of the leaves of Lasiantheraafricana and Dennettiatripetala on clinical isolates. J Advs Biol Biotechnol. 2016;8(4):1-9. https://doi.org/10.9734/JABB/2016/28291.

18. Achuba Fl. Role of bitter leaf (Vernoniaamygdalina) extract in prevention of renal toxicity induced by crude petroleum contaminated diets in rats. Int J Vet Sci Med. 2018;6(2):172-7 https://doi.org/10.1016/j.ijvsm.2018.07.002.

19. George BO, Okpoghono J, Osioma E, Aina OO. Changes in oxidative indices in Plasmodium Berghei infected mice treated with aqueous extract of Aframomum Sceptrum. Front Sci. 2012;2(1):6-9. https://doi.org/10.5923/j.fs.2 0120201.02

20. Sofowora A. Medicinal plants and traditional medicine in Africa. Ibadan: Spectrum Books Ltd; 1993. p. 289-90.

21. Trease GE, Evans WC. Pharmacognosy. 11th ed. London: BailliereTindall Ltd; 1989. p. 60-75.

22. Harborne JB. Phytochemical Methods. London: Chapman and Hall, Ltd; 1973. p. 49-188.

23. Mediesse-Kengne F, Woguia AL, Fogue P, Atogho-Tiedeu B, Simo G, Boudjeko T. Antioxidant properties of cell wall polysaccharides of Stevia rebaudiana leaves. J Cost Lif Med. 2014;2(12):962-9. https://doi.org/10.1186/ s13104-015-1703-x.

24. Oyedemi SO, Bradley G, Afolayan AJ. In vitro and in vivo antioxidant activities of aqueous extract of Strychonos henningsii Gilg. Afr J Pharm Pharmacol. 2010:4:70-8.

25. Amir M, Mujeeb M, Khan A, Ashraf K, Sharma D, Aqil M. Phytochemical analysis and in vitro antioxidant activity of Uncariagambir. Int J Green Pharm. 2012;6(1):67-72. https://doi.org/10.4103/0973-8258.97136. 
26. Iserhienrhien LO, Okolie PN. Phytochemical screening and in vitro antioxidant properties of methanol and aqueous leaf extracts of Geophila obvallata. AJRB. 2018;3(2):1-11.

27. Garcia-Alonso M, de Pascual-Teresa S, Santos-Buelga C, Rivas-Gonzalo JC. Evaluation of the antioxidant properties of fruits. Food Chem. 2004;84(1):138. https://doi.org/10.1016/S0308-8146(03)00160-2.

28. Animal Research Ethics. A handbook of USP researchers, vol. 2. 1st ed: Research office publisher. Suva: University of South Pacific; 2009. p. 3-4.

29. World Medical Association. WMA statement on animal use in biomedical research. 2016

30. Ichipi-Ifukor PC, Asagba SO, Nwose C. Potentiating role of palm oil (Elaeisguineensis) and its extracts in cadmium-induced alteration of amino Transferases. Thai J Pharmaceut Sci. 2019;43(1):38-46.

31. Gutteridge JMC, Wilkins C. Copper dependent hydroxyl radical damage to ascorbic acid. Formation of a thiobarbiturie acid reactive products. FEBS Lett. 1982;137(2):327-40. https://doi.org/10.1016/0014-5793(82)80377-3.

32. Ellman GC. Tissue sulflydryl groups. Arch Biochem Biophys. 1959;82(1):70-7. https://doi.org/10.1016/0003-9861(59)90090-6.

33. Cohen HJ, Betcher-Lange Kessler DL, Rajagopalan KV. Hepatic sulphite oxidase congruency in mitochondria of prosthetic groups and activity. J Biol Chem. 1972;247(2):7759-66. https://doi.org/10.1016/S0021-9258(19)44588-2.

34. Misra HP, Fridovich I. The role of superoxide ion in the auto-oxidation of epinephrine and a simple assay for superoxide dismutase. J Biol Chem. 1972;247(10):3170-5. https://doi.org/10.1016/S0021-9258(19)45228-9.

35. Habig WH, Pabst MJ, Jakoby WB. Glutathione-s-transferases: first enzymic step in mercapturic acid formation. J Biol Chem. 1974;249(22):7130-9. https://doi.org/10.1016/S0021-9258(19)42083-8.

36. Khan MR, Rizvi W, Khan RA, Sheen S. Carbon tetrachloride induced nephrotoxicity in rats: protective role of Digera muricata. J Ethnopharmacol. 2008;122:91-9 DOl: https://doi.org/10.1016/j.jep.2008.12.006.

37. Gowda S, Desai PB, Kulkarni SS, Hull W, Math AAK, Vernekar SN. Markers of renal function tests. N Am J Med Sci. 2010;2(4):170-3.

38. Ndukwu BC, Ben-Nwadibia BN. Ethnomedicinal aspects of plants used as spices and condiments in Niger Delta area of Nigeria. Ethnonobotanicals Leaflets. 2005;10:10.

39. Omage SO, Orhue NEJ, Omage K. Evaluation of the phytochemical content, in vitro antioxidant capacity, and biochemical and histological effects of Dennettia tripetala fruits in healthy rats. Food Sci Nutr. 2019;7(1):65-75. https://doi.org/10.1002/fsn3.792.

40. Maxwell A, Seepersaud M, Pingal P, Mootoo DR, Reynolds WF. 3-beta amino spirosolane steroidal alkaloids from Solanum triste. J Nat Prod. 1995;58(4): 625-8. https://doi.org/10.1021/np50118a027.

41. Soetan $\mathrm{KO}$, Aiyelaagbe $\mathrm{OO}$. The need for bioactivity-safety evaluation and conservation of medicinal plants - a review. J Med Plants Res. 2009;3(5): 324-8.

42. Onakurhefe P, Achuba Fl, George BO. Phytochemical Analysis and Chemical Characterization of Extracts and Blended Mixture of Palm Oil Leaf. Trop Nat Prod Res. 2019;3(9):282-97. https://doi.org/10.26538/tjnpr/v3i9.2.

43. Moukette BM, Pieme CA, Njimou JR, Nya Biapa CP, Marco B, Ngogang JY. In vitro antioxidant properties, free radicals scavenging activities of extracts and polyphenol composition of a non-timber forest product used as spice: Monodora myristica. Biol Res. 2015;48(1):15. https://doi.org/10.1186/s40659015-0003-1.

44. Kumar M, Gupta V, Kumari P, Reddy C, Jha B. Assessment of nutrient composition and antioxidant potential of Caulerpaceae seaweeds. J Food Comp Anal. 2011;24(2):270-8. https://doi.org/10.1016/j.jfca.2010.07.007.

45. Vishnu R, Nisha R, Jamuna S, Paulsamy S. Quantification of total phenolics and flavonoids and evaluation of in vitro antioxidant properties of methanolic leaf extract of Tarenna asiatica-an endemic medicinal plant species of Maruthamali hills, Western Ghats, Tami Nadu. J Res Plant Sci. 2013;2(2):196-204

46. Benedec D, Vlase L, Oniga I, Mot AC, Damian G, Hanganu D, et al. Polyphenolic composition, antioxidant and antibacterial activities for two Romanian subspecies of Achillea distans Waldst. et Kit. ex Willd. Molecules 24. 2013;18(8):8725-39

47. Larayetan R, Osanekwu S, Sokwo M. Phytochemical components of methanolic fruit extract of Dennettia tripetala. J Funct Materials Biomolecules. 2018;2(2):48-52.

48. Asagba SO, Ichipi-Ifukor PC, Ichipi-Ifukor RN, Oyem JC. Palm oil fractions Alter acute cadmium mediated Haematotoxicity. Galician Med J. 2019;26(3): E201933.
49. Woldemeskel M. Toxicologic pathology of the reproductive system. Reprod Developtl Toxicol. 2017:1209-41. https://doi.org/10.1016/b978-0-12-8042397.00064-0.

50. Achuba Fl, Obaremi C. Effect of selenium fortified diet on inflammatory markers in Wistar albino rats. Nig J Pharm Bio Res. 2018; 3(3):209-16.

51. Okpoghono J, Achuba Fl, George BO. Protective effect of Monodora myristica extracts on crude petroleum oil-contaminated catfish (Clarias gariepinus) diet in rats. Intl J Vet Sci Med. 2018;6(1):117-22 https://doi.org/1 0.1016/j.ijvsm.2018.03.006.

52. Kweki GR, Ichipi-Ifukor PC, Asagba SO. High caffeine-containing energy drink-induced metabolic stress in rats. SJMLS. 2018;3(3):86-93.

53. Atinaya DU, Ichipi-Ifukor PC, George BO, Okpoghono J. Cyanide-induced metabolic stress; the role of Aframomum sceptrum aqueous extract (ASAE). SJMLS. 2019;4(3):108-19.

54. Ogbeke Gl, George BO, Ichipi-Ifukor PC. Aframomum Sceptrum Modulation of Renal Function in Monosodium Glutamate (MSG) Induced Toxicity. UK J Pharmaceut Biosci (UKJPB). 2016;4(4):54-60.

55. Ita SO, Aluko EO, Atang DE, Antai AB, Osim EE. Vitamin C or E supplementation ameliorates Nigerian bonny light crude oil induced erythrocytes haemolysis in male wistar rats. Biochem Mol Biol. 2013;1(3):4451. https://doi.org/10.12966/bmb.10.01.2013.

56. Morrison G. Serum Chloride. In: Walker HK, Hall WD, Hurst JW, editors. Clinical methods: the history, physical, and laboratory examinations. 3rd ed. Boston: Butterworths; 1990. Chapter 197. Available from: https://www.ncbi. nlm.nih.gov/books/NBK309/.

57. Pfortmueller CA, Uehlinger D, von Haehling S, Schefold JC. Serum chloride levels in critical illness-the hidden story. Intens Care Med Expertl. 2018;6(1): 10 https://doi.org/10.1186/s40635-018-0174-5

58. Achuba Fl. Modulation of crude oil induced alteration of oxidative stress indices in rat by red palm oil. J Appl Sci Environ Mgt. 2018;22(6):929-32. https://doi.org/10.4314/jasem.v22i6.15.

59. Ichipi-Ifukor PC, Asagba SO, Kweki GR, Nwose C. Attenuation of Oxidative Enzymes Induction in Palm Oil Fractions Pre-treated Cadmium Intoxicated Rats. Trop J Nat Prod Res. 2019;3(4):107-12. https://doi.org/10.26538/tjnpr/v3 i4.2.

60. Asagba SO. Alteration in the activity of oxidative enzymes in the tissues of male Wistar Albino rats exposed to cadmium. Int J Occup Med Environ Health. 2010;23(1):55-62 DOI: https://doi.org/10.2478/v10001-010-0002-y [PMid: 20442063].

61. Ichipi-Ifukor PC, Ogbeke Gl, George BO. Possible mechanism of Aframomum Sceptrum extracts mediated modulation of renal function after monosodium glutamate exposure. Gal Med J. 2019;26(44):E201946.

62. Higuchi M. Antioxidant properties of wheat bran against oxidative stress. Wheat Rice Dis Prev Health. 2014:181-99. https://doi.org/10.1016/b9780-12-401716-0.00015-5.

63. Fanucchi MV. Development of antioxidant and xenobiotic metabolizing enzyme systems. The Lung. 2014;2:223-31. https://doi.org/10.1016/b9780-12-799941-8.00011-0.

64. Woolbright BL, Li F, Xie Y, Farhood A, Fickert P, Trauner M, et al. Lithocholic acid feeding results in direct hepatotoxicity independent of neutrophil function in mice. Tox Lett. 2014;228(1):56-66. https://doi.org/10.1016/j. toxlet.2014.04.001.

65. Ballatori N, Krance SM, Notenboom S, Shi S, Tieu K, Hammond CL. Glutathione dysregulation and the etiology and progression of human diseases. Biol Chem. 2009;390(3):191-214 https://doi.org/10.1515/BC.2009. 033.

66. Owen JB, Butterfield DA. Measurement of Oxidized/Reduced Glutathione Ratio. In: Bross, Niels, editors. Prot. Misfolding Cell. Stress Dis. Aging; 2010. p. 269-77. https://doi.org/10.1007/978-1-60761-756-3_18.

67. Zitka O, Skalickova S, Gumulec J, Masarik M, Adam V, Hubalek J, et al. Redox status expressed as GSH:GSSG ratio as a marker for oxidative stress in paediatrictumour patients. Oncol Lett. 2012;4(6):1247-53 https://doi.org/10.3 892/ol.2012.931.

68. Cheng SB, Liu HT, Chen SY, Lin PT, Lai CYH, YC. Changes of oxidative stress, glutathione, and its dependent antioxidant enzyme activities in patients with hepatocellular carcinoma before and after tumor resection. PLoS One. 2017;12(1):e0170016. https://doi.org/10.1371/journal.pone.0170016.

69. Tan BL, Norhaizan ME, Liew WP, Sulaiman RH. Antioxidant and oxidative stress: a mutual interplay in age-related diseases. Front Pharmacol. 2018;9: 1162 https://doi.org/10.3389/fphar.2018.01162. 
70. Malaquin N, Carrier-Leclerc A, Dessureault M, Rodier F. DDR-mediated crosstalk between DNA damaged cells and their microenvironment. Front Genet. 2015;6:94. https://doi.org/10.3389/fgene.2015.00094.

71. Olivieri F, Albertini MC, Orciani M, Ceka A, Cricca M, Procopio AD, et al. DNA damage response (DDR) and senescence: shuttled inflamma-miRNAs on the stage of inflamm-aging. Oncotarget. 2015;6:35509-21. https://doi.org/10.1 8632/oncotarget.5899a.

\section{Publisher's Note}

Springer Nature remains neutral with regard to jurisdictional claims in published maps and institutional affiliations.

\section{Submit your manuscript to a SpringerOpen ${ }^{\circ}$ journal and benefit from:}

- Convenient online submission

- Rigorous peer review

- Open access: articles freely available online

- High visibility within the field

- Retaining the copyright to your article

Submit your next manuscript at $\boldsymbol{\nabla}$ springeropen.com 